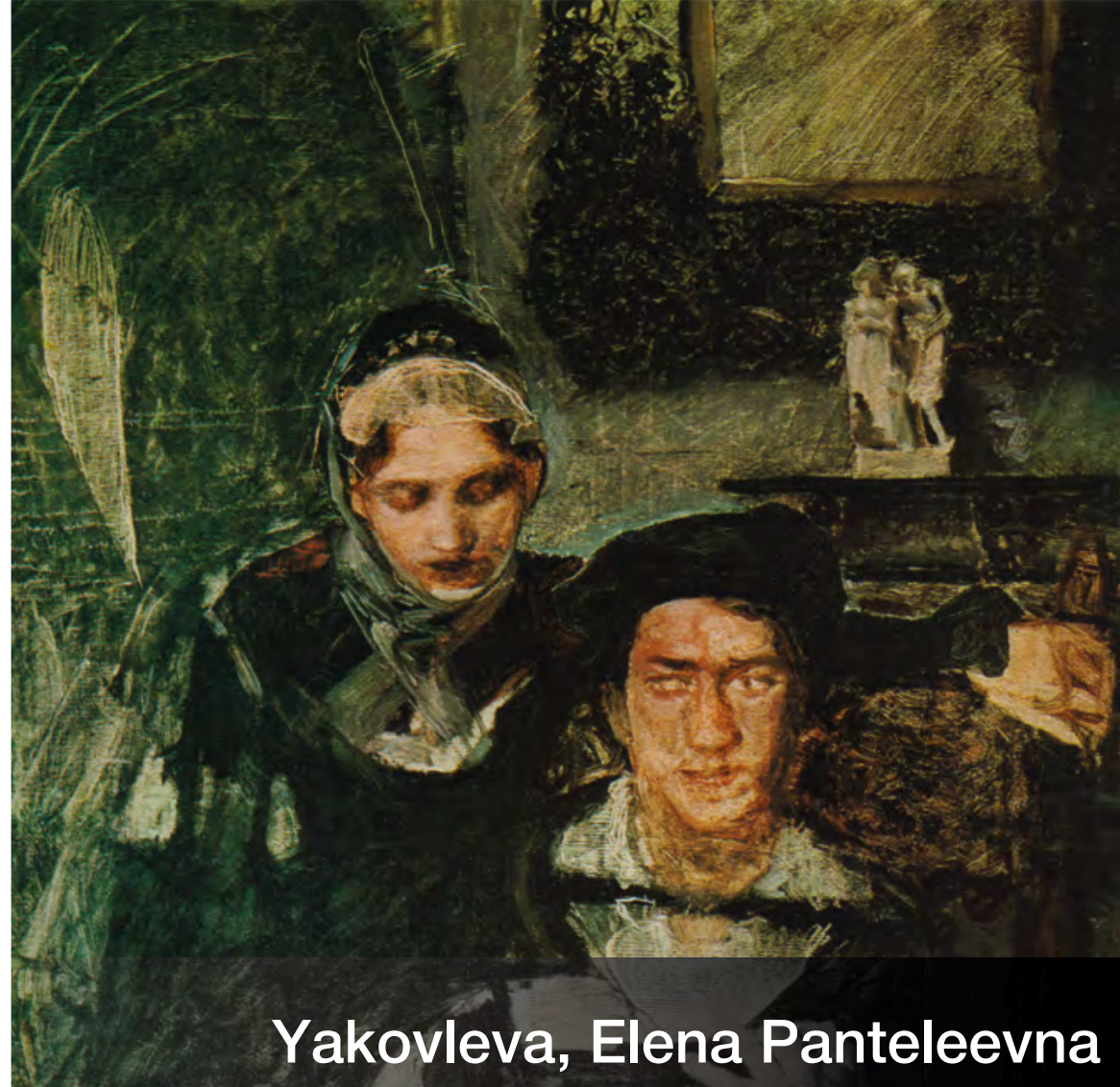

Russian Institute of Art History,

St. Petersburg, Russian Federation

\title{
О ПРОИЗВЕДЕНИЯХ
}

H.K. РЕРИХА

В ПРИМОРСКОЙ

ГОСУДАРСТВЕННОЙ

КАРТИННОЙГАЛЕРЕЕ

OF NICHOLAS K. ROERICH

IN THE PRIMORYE STATE

ART GALLERY

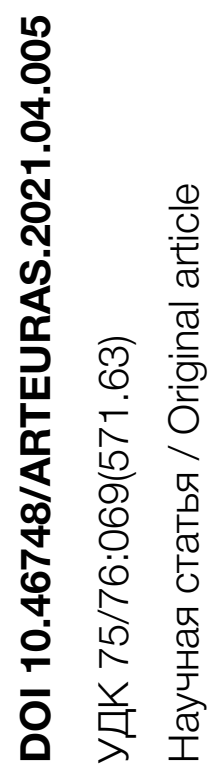




\section{АННОТАЦИЯ}

В статье, основанной на материалах многолетних исследований автора, рассматриваются два произведения Николая Константиновича Рериха из собрания Приморской государственной картинной галереи. Внимание заостряется на причастности пейзажа «Туман» (1907) к серии «Финляндских этюдов» художника, а этюда «Дорожка» (1908) - к известной петербургской коллекции, в 1910-е годы принадлежавшей А.В. и Е.Л. Румановым. В настоящее время коллекция Румановых рассеяна по двадцати пяти государственным музеям бывшего Советского Союза. Больше всего произведений входит в собрание Русского музея. В Приморской картинной галерее хранится всего одна работа - этюд Рериха «Дорожка», и по ней довольно сложно судить о масштабе коллекции Румановых и месте данного этюда в числе других работ художника, входивших в ее состав. Уточнение истории создания и бытования обоих пейзажей Н.К. Рериха из собрания Приморской картинной галереи имеет важное значение для их изучения и научной каталогизации, а также для просветительской деятельности галереи.

КЛЮЧЕВЫЕ СЛОВА: Приморская картинная галерея, пейзажи Н.К. Рериха, серия «Финляндские этюды», коллекция А.В. и Е.Л. Румановых.

\begin{abstract}
The article, based on the materials of the author's long-term research, examines two works by Nicholas Konstantinovich Roerich from the collection of the Primorye State Art Gallery. Attention is focused on the involvement of the landscape "Fog" (1907) in the series of "Finnish sketches" by the artist, and the sketch "Path" (1908) - in the famous St. Petersburg collection, in the 1910s owned by A.V. and E.L. Rumanov. Currently, the Rumanov collection is scattered across twenty-five state museums of the former Soviet Union. Most of the works are included in the collection of the Russian Museum. The Primorye Art Gallery has only one work - Roerich's sketch "The Path", and it is quite difficult to judge the scale of the Rumanov collection and the place of this sketch among other works of the artist that were part of it. Clarification of the history of the creation and existence of both landscapes by N.K. Roerich from the collection of the Primorye Art Gallery is important for their study and scientific cataloging, as well as for the educational activities of the gallery.
\end{abstract}

KEYWORDS: Primorye State Art Gallery, landscapes, N.K. Roerich, Finnish studies, Rumanovs collection. 
В собрании Приморской государственной картинной галереи хранятся два произведения известного русского художника Николая Константиновича Рериха (1874-1947) — пейзажи «туман», или «Туман в лесу» (1907), и «Дорожка. Этюд» (1908). Оба описаны, репродуцированы и опубликованы сотрудниками Приморской картинной галереи [11, с. 41 (ил), 63, кат. 67, 68].

При жизни художника названия произведений и краткие их описания вошли в списки работ Н.К. Рериха в монографии о его творчестве [12, с. 215,216 ; 17 , с. 118,$119 ; 24$, р. 29]. В советский период пейзажи с несколько измененными названиями «Туман в лесу» и «Дорожка» получили отражение в перечне произведений Н.К. Рериха 1885-1947 годов «Художественное наследие Николая Константиновича Рериха», составленном В.В. Соколовским [15, с. 268, 269].

И всё же хотелось бы вновь заострить внимание на этих небольших по размерам пейзажах пастелью 1900-х годов такого крупного мастера, каким является Николай Константинович Рерих (рис. 1), вошедший в историю своей многогранной деятельностью живописца - станковиста и монументалиста, иконописца, художника театра, ученого-археолога, литератора, педагога и общественного деятеля мирового значения.

Цель статьи состоит в том, чтобы обосновать причастность пейзажа «Туман» к серии «Финляндских этюдов» Н.К. Рериха и обратиться к истокам создания и бытования этюда «Дорожка», связанного с известной петербургской художественной коллекцией 1910-х годов.

Пастель «Туман» (рис. 2) написана в 1907 году, о чем свидетельствует авторская надпись справа внизу на изображении, включающая подпись художника и дату: Н. Рерихъ 907. На обороте картона имеются две выставочные наклейки, содержащие сведения о том, что произведение экспонировалось на таких значимых выставках конца 1900-х годов, как «Салон», устроенный художественным критиком С.К. Маковским в Петербурге в конце 1908 - начале 1909 года, и VII выставка «Союза русских художников», проходившая в Москве с 26 декабря 1909 года по 7 февраля 1910 года. Подтверждают эти сведения каталоги обеих выставок. Так, в каталоге московской выставки «Союза русских художников» «Туман» значится под № 247 в числе других шестидесяти произведений Рериха [5, с. 19-21, № 219-280], а в каталоге «Салона» под № 303 среди сорока трех работ художника [14, с. 55-57, № 288-331], в том числе десяти рассеянных в каталоге пейзажей, имеющих отношение к серии «Финляндские этюды».

Пейзаж «Туман» неоднократно упоминался рецензентами выставок как заслуживающее внимания произведение. Так, художественный
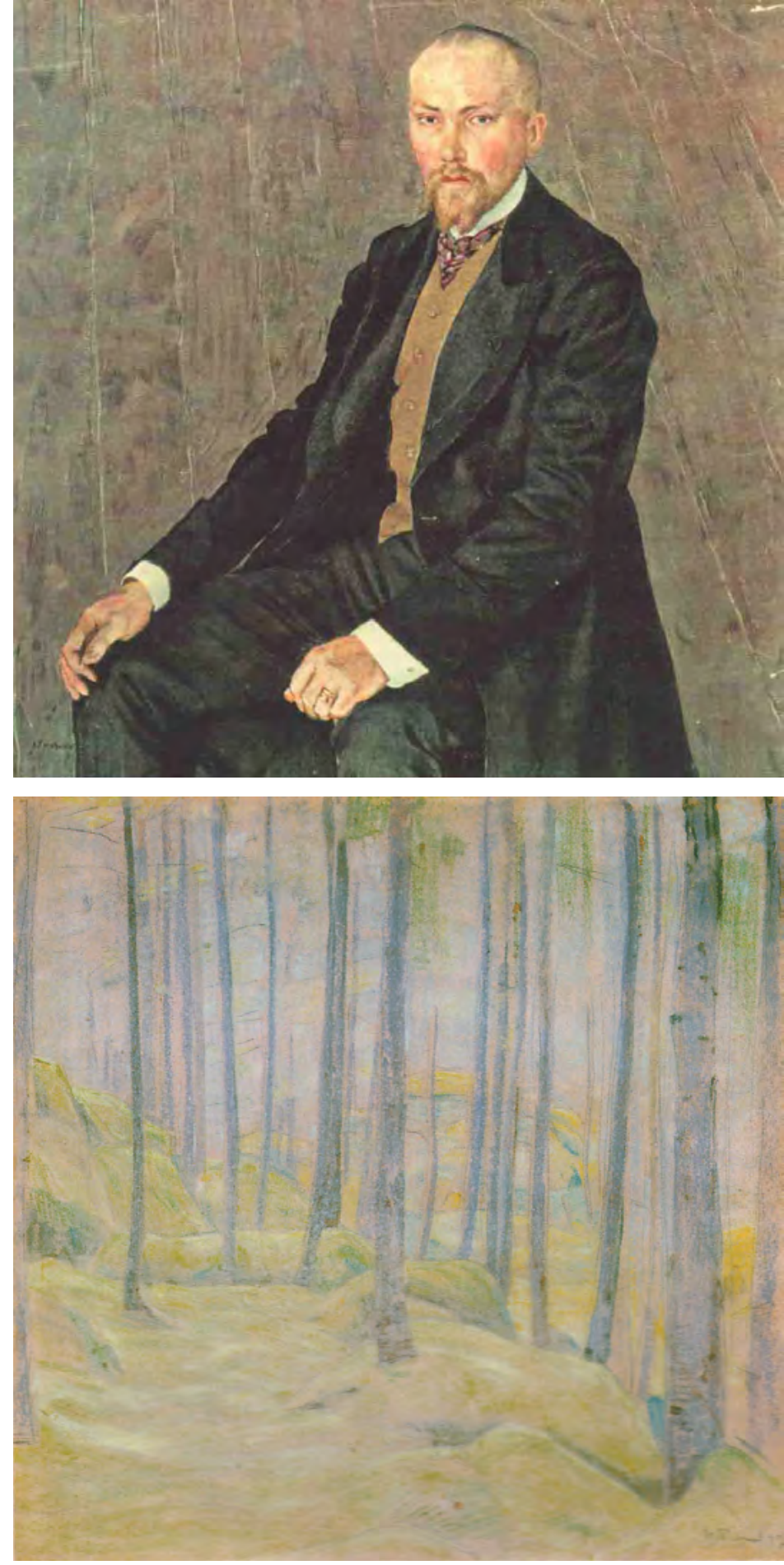

1. А.Я. Головин.

Портрет Николая Константиновича Рериха.

1907.

Холст, темпера, пастель. $104 \times 104$

Государственная Третьяковская галерея [21, c. 3]

\section{2. Н.К. Рерих.}

Туман.

1907.

Бумага на картоне,

пастель, карандаш, тушь.

$47,5 \times 47,5$

Приморская

государственная

картинная галерея

[11, c. 41] критик Иван Лазаревский наряду с работами «Седая Финляндия» (рис. 3) и «Пунка-Харью» (рис. 4) отнес «Туман» к числу наиболее понравившихся ему пейзажей Рериха на выставке «Салона». Критик писал: «Произведения Рериха - центр интереса теперешнего Салона. <...> Характерно, что Рериха привлекает природа Финляндии; в его этюдах чувствуется, как верно понял и воспринял он типичную красоту севера» [6, с. 6]. Лазаревскому вторил репортер «Петербургского листка». Он писал: «Художник Н.К. Рерих, известный знаток русской художественной археологии, занял своими картинами целый зал. <...> Рядом со сказочными мистическими сюжетами художник дает целую 


\section{ART OF THE
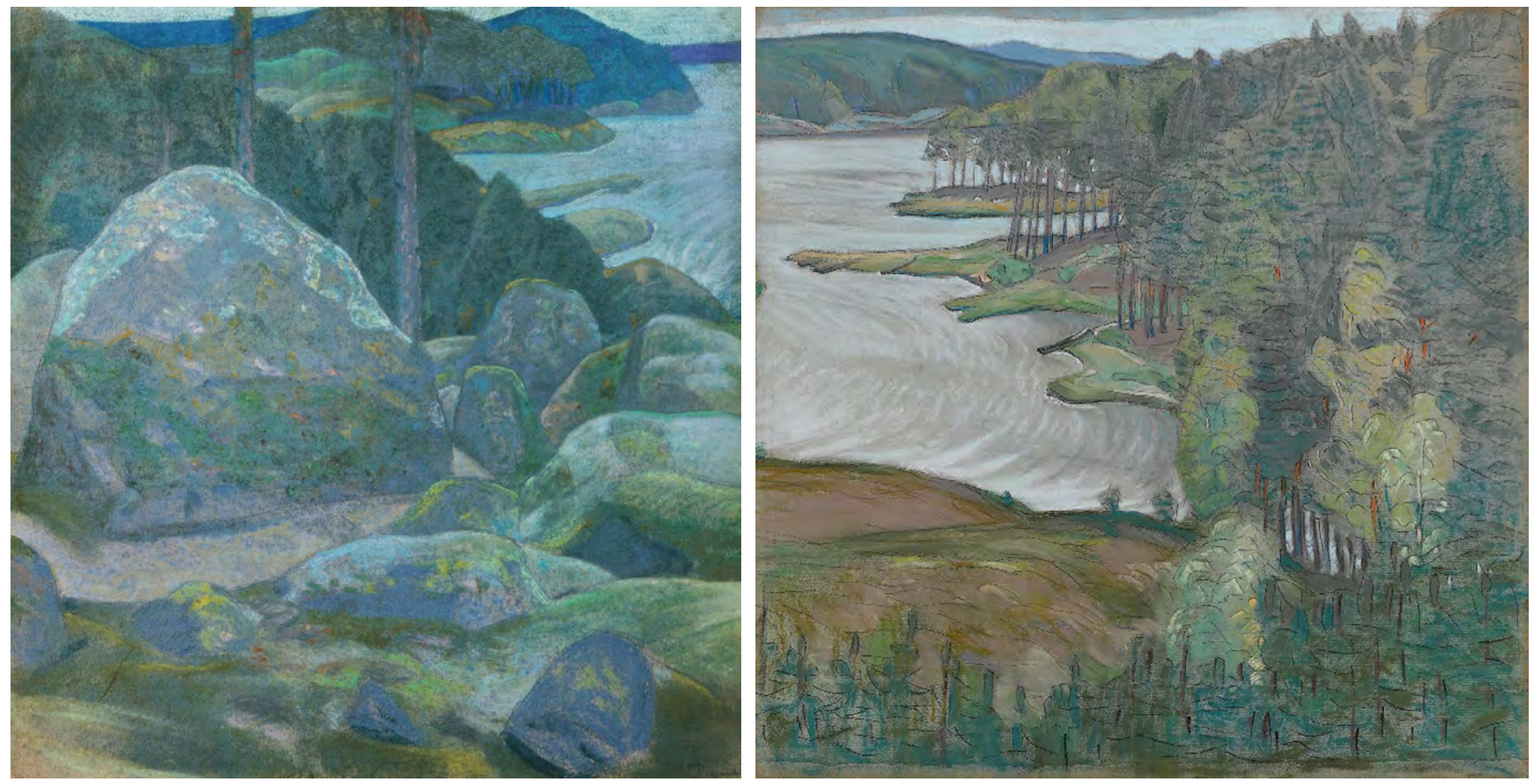

\section{H.K. Рерих.}

\section{Седая Финляндия.}

1907.

Картон, пастель, темпера.

$44 \times 43,5$

Государственный

Русский музей

[8, с. 79 , кат. 50]

\section{4. Н.К. Рерих.}

Пунка-Харью.

\section{Финляндия.}

1907.

Бумага, пастель,

итальянский карандаш.

$46,5 \times 46,5$

Государственная

Третьяковская галерея

[13, с. 46, ил. 9] серию превосходных этюдов с натуры, в которых он передал вековой мох на холодных каменных громадах Финляндии» [2, с. 3].

После завершения VII выставки «Союза русских художников» в Москве пейзаж «Туман» был продан москвичке О.А. Лопатиной, о чем свидетельствуют надпись на обороте картины и списки произведений Рериха [12, с. 215; 18, с. 118; 24, р. 29]. После Октябрьской революции 1917 года через Отдел по делам музеев и охраны памятников искусства и старины Народного комиссариата просвещения картина поступила на постоянное хранение в собрание Государственной Третьяковской галереи с названием «Туман в лесу», где она находилась вплоть до 1930 года, и уже оттуда была передана в художественное собрание Владивостокского государственного музея, в 1938 году преобразованного в Приморский краеведческий музей имени В.К. Арсеньева, а в 1966 году - в Приморскую государственную краевую картинную галерею. С тех пор пастель с авторским названием «Туман» наряду с этюдом «Дорожка» представляет в художественном музее Владивостока живопись Николая Рериха, уже заявившего о себе к концу 1900-х годов на российской и европейской художественной сцене.
Стоит отметить, что во всех прижизненных перечнях произведений Рериха 1907 годом датируется серия «Финляндские этюды». Как известно, понятие «серия» в изобразительном искусстве означает несколько произведений, объединенных общим посылом, идеей, темой, образами, стилем, форматом и так далее. В данном случае серия «Финляндские этюды» объединяет свыше двадцати натурных пейзажей пастелью, написанных Рерихом во время его пребывания в разных местах Финляндии. Большинство пейзажей имеет квадратный формат, одна сторона которого равняется примерно сорока пяти (плюс-минус двум) сантиметрам. Согласно этим параметрам, а также тематически, стилистически и образно-художественно пастель «Туман», безусловно, входит в эту серию, что подтверждают и списки произведений автора.

Как представляется, данный факт необходимо отразить в названии и музейном описании произведения, что позволит официально закрепить пейзаж «Тман» в серии «Финляндских этюдов» Н.К. Рериха и поставить его в один ряд с широко известными этюдами этой серии. В настоящее время они хранятся в разных государственных и частных собраниях. Так, например, пейзаж «Пунка-Харью. Финляндия» (1907), экспонировавшийся на VII выставке «Союза русских 


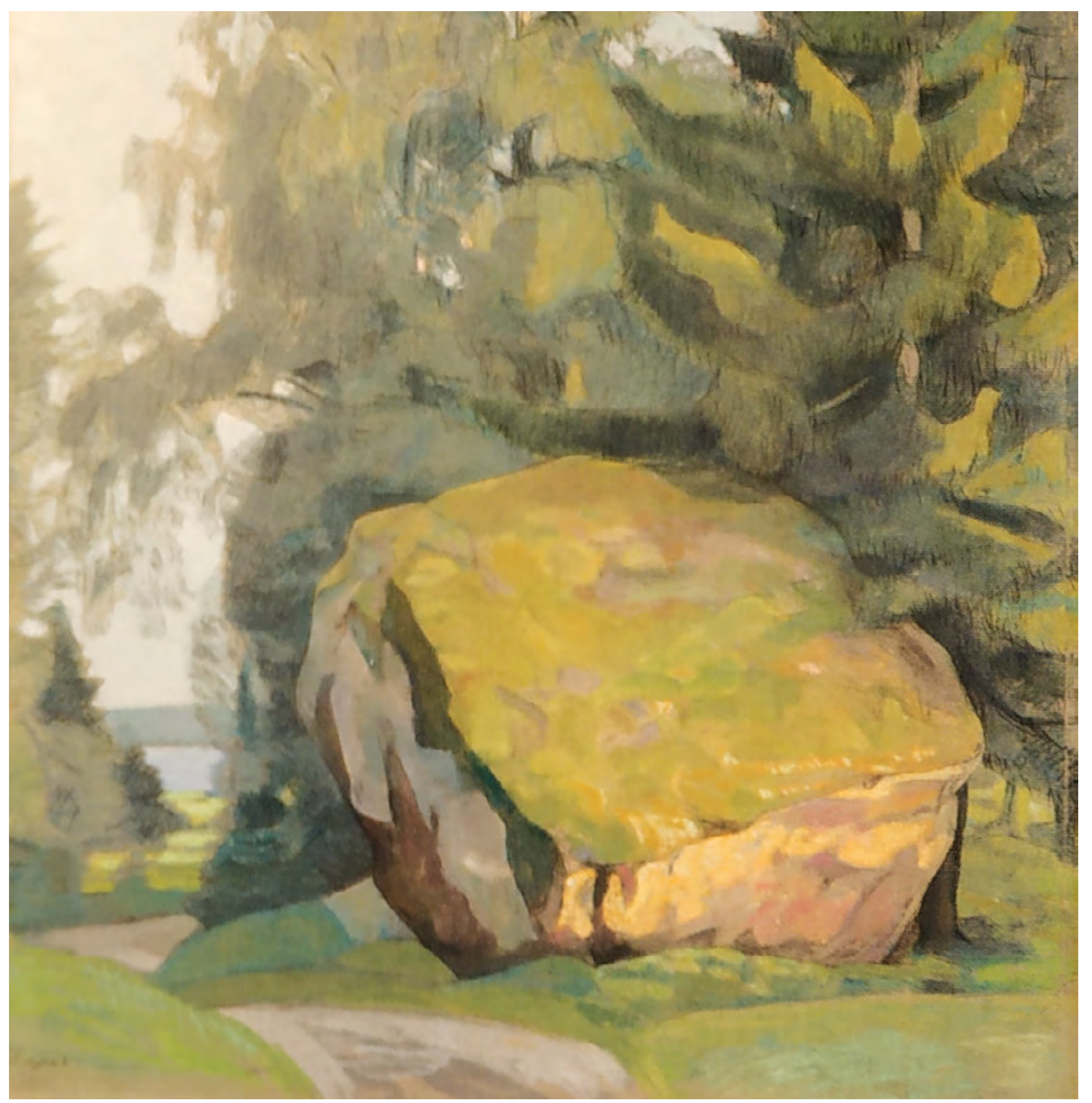

художников» и изначально принадлежавший г-же Лоховой из Москвы [12, с. 215], после революции 1917 года входил в Государственный музейный фонд, откуда в 1927 году поступил в Государственную Третьяковскую галерею [13, с. 46, ил. 9].

В собрании Государственного Русского музея хранится пейзаж «Седая Финляндия» (1907), первоначально принадлежавший А.Л. Липовскому [12, с. 215; 17, с. 118; 24, р. 29] - педагогу и литературоведу, преподавателю знаменитой Школы К.И. Мая в Петербурге, в которой учился Н.К. Рерих.
В Русский музей произведение поступило в 1971 году из Дзержинского райфинотдела, а ранее оно входило в ленинградскую коллекцию Б.А. Бланкштейна [4, с. 150, № 771].

«Пейзаж с придорожным камнем» (1907, рис. 5) автор подарил известному петербургскому коллекционеру, сенатору, члену Общества поощрения художеств Е.Е. Рейтерну [12, с. 215; 19, с. 325; 24, р. 29]. На оборотной стороне произведения художник сделал дарственную надпись: «Глубокоуважаемому искреннему любителю искусства
5. Н.К. Рерих.

Пейзаж

с придорожным камнем.

1907.

Картон, пастель, темпера. $46 \times 47$

Государственный Русский музей [8, с. 83, кат. 59] 


\section{ART OF THE

\section{6. Н.К. Рерих.}

Пейзаж с валунами.

Конец 1900-х.

Картон, пастель.

$47 \times 47$

Государственный

Русский музей

[8, с. 82, кат. 58]

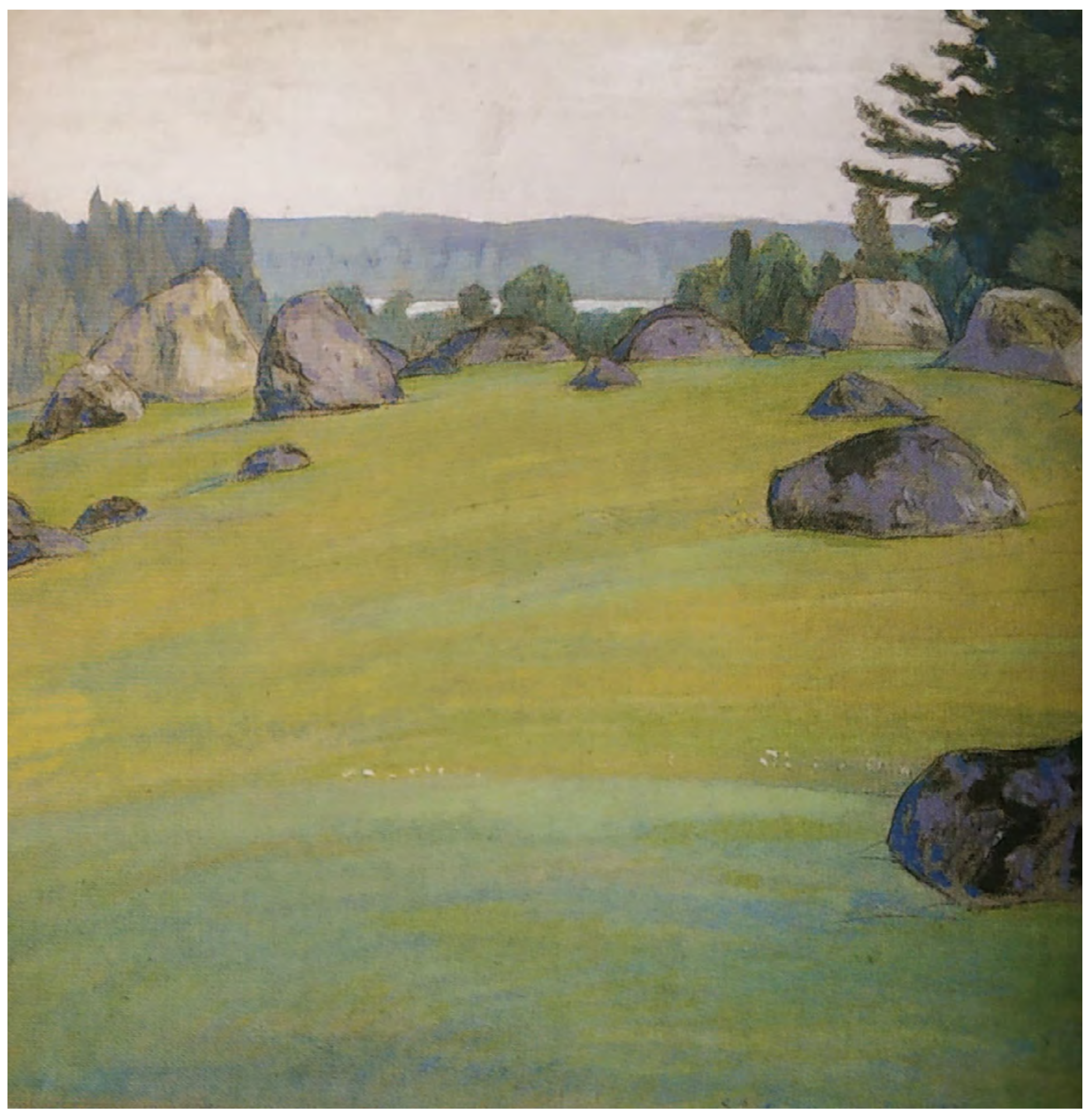

Евграфу Евграфовичу Рейтерну на добрую память о добром сосьдствъ въ Финляндіи душевно преданный Н. Рерихъ 8 октября 1907 г. Спб». После смерти Рейтерна, в 1919 году пейзаж поступил в собрание Русского музея [4, с. 150, № 772].

Образно и стилистически близок этому произведению «Пейзаж с валунами» (рис. 6), однако в Русском музее, куда он поступил в 1959 году от ленинградца И.Л. Марголина, пейзаж датирован концом 1900-х годов [4, с. 150, № 773]. Если всё же удастся определить, что произведение было создано в 1907 году, то вполне возможно, оно могло носить авторское название «Камни», под которым значатся три произведения, в 1910-е годы входившие в коллекции петербуржцев М.И. Рабиновича (Рославлева), С.С. Митусова и С.К. Маковского [12, с. 215; 17, с. 118; 24, р. 29].

В серию «Финляндских этюдов» входит также пейзаж с элементами жанра с авторским названием «Охотники» (1907, рис. 7), первоначально принадлежавший петербуржцу Б.Г. Власьеву [12, с. 215], а ныне - частному лицу [1, с. 70, ил. 152]. 

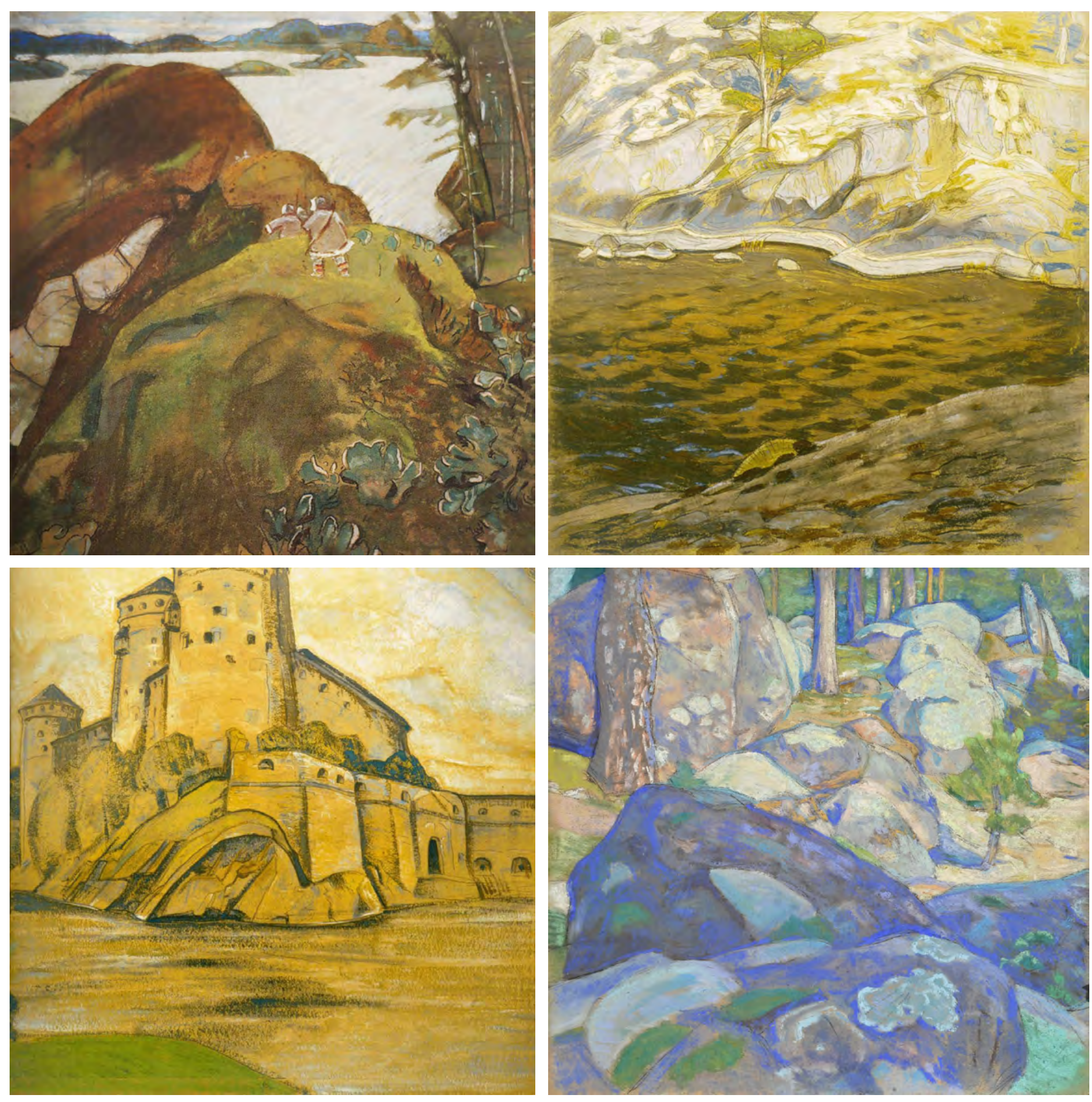

Так же это произведения «Вентила» (1907, рис. 8), первым владельцем которого был режиссер Н.Н. Евреинов [12, с. 215], и пейзаж «Нейшлот. Олафсборг» (или «Нислот. Олафсбор») (1907, рис. 9), который приобрела у автора г-жа Иения-Дунья, проживавшая в Финляндии [12, с. 215; 17, с. 118]. В настоящее время оба произведения хранятся в Государственном музее искусства народов Востока, куда они поступили из Музея Рерихов Международного Центра Рерихов [16, с. 210 (ил.), 704-705; с. 211 (ил.), 705].
Другие выявленные произведения из этой серии имеют вытянутый по горизонтали формат. Известные нам работы принадлежат главным образом частным владельцам. Ряд пейзажей, упомянутых в прижизненных списках произведений художника, пока не выявлен. Списки же свидетельствуют о том, что подавляющее большинство этих «молчаливых финляндских этюдов» (выражение искусствоведа С.Р. Эрнста [17, с. 90]), уже в первой половине 1910-х годов принадлежало отечественным и зарубежным владельцам, в число

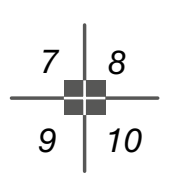

\section{7. Н.К. Рерих.}

\section{Охотники.}

1907.

Картон, пастель, темпера, итальянский карандаш.

$45,5 \times 45,5$

Частное собрание

[1, с. 70, ил. 152]

\section{8. Н.К. Рерих.}

\section{Вентила.}

1907.

Картон, темпера, пастель.

$47,1 \times 47,1$

Государственный музей

искусства народов

Востока

[16, c. 210]

\section{9. Н.К. Рерих.}

\section{Нейшлот. Олафсборг.}

1907.

Картон, темпера, пастель.

$47,1 \times 47,1$

Государственный музей

искусства народов

Востока

[16, c. 211]

\section{0. Н.К. Рерих.}

\section{Финляндия.}

1907.

Картон, пастель.

$47,5 \times 47$

Частное собрание.

Фотография из частного архива 


$$
\begin{aligned}
& \text { ART OF THE } \\
& X X-X X I \text { CENTURIES }
\end{aligned}
$$

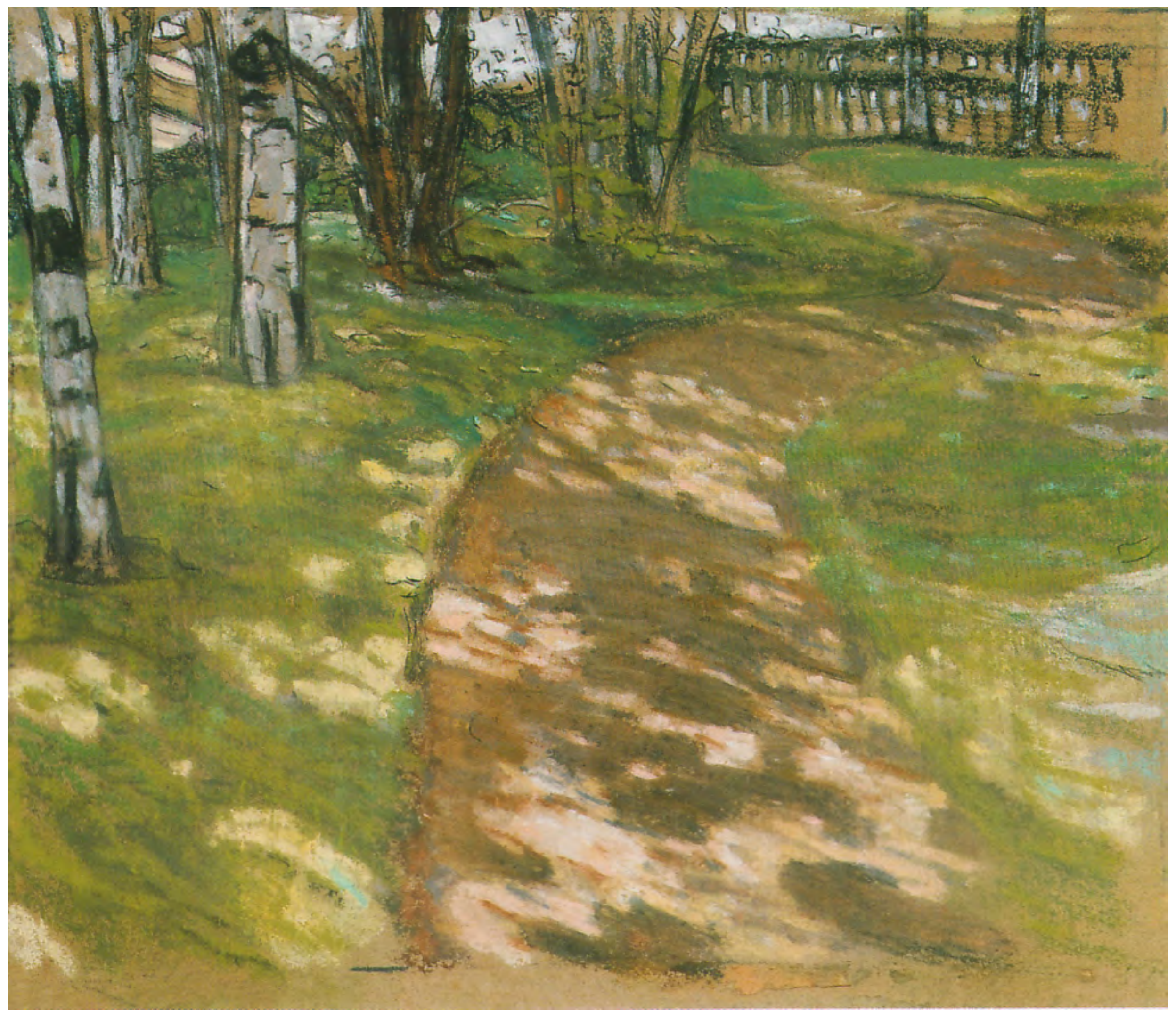

11. Н.К. Рерих. Дорожка. 1908.

Бумага желтая на картоне, пастель.

\section{$32,5 \times 38$}

\section{Приморская}

\section{государственная}

картинная галерея

[11, c. 41] которых, помимо названных, входили В.В. Голубев - выдающийся востоковед, искусствовед и археолог (этюд «Иванов огонь»), профессор В.А. Щавинский - известный коллекционер голландской и фламандской живописи, ученый-химик (пейзаж «Лавола»), барон де Бай - знаменитый французский археолог и путешественник (пастель «Священное место»), поэт Константин Льдов (пастель «Лес») и др. [12, с. 215; 19]. Современное местонахождение произведений серии «Финляндские этюды» подтверждает их высокий художественный уровень. Факт причастности к данной серии пейзажа «туман» непременно должен быть отмечен в документах галереи и Государственного музейного фонда России.

Пастель Николая Рериха «Дорожка» (рис. 11) поступила в собрание Приморской картинной галереи в 1930 году, но уже не из Москвы, а из Ленинграда. 

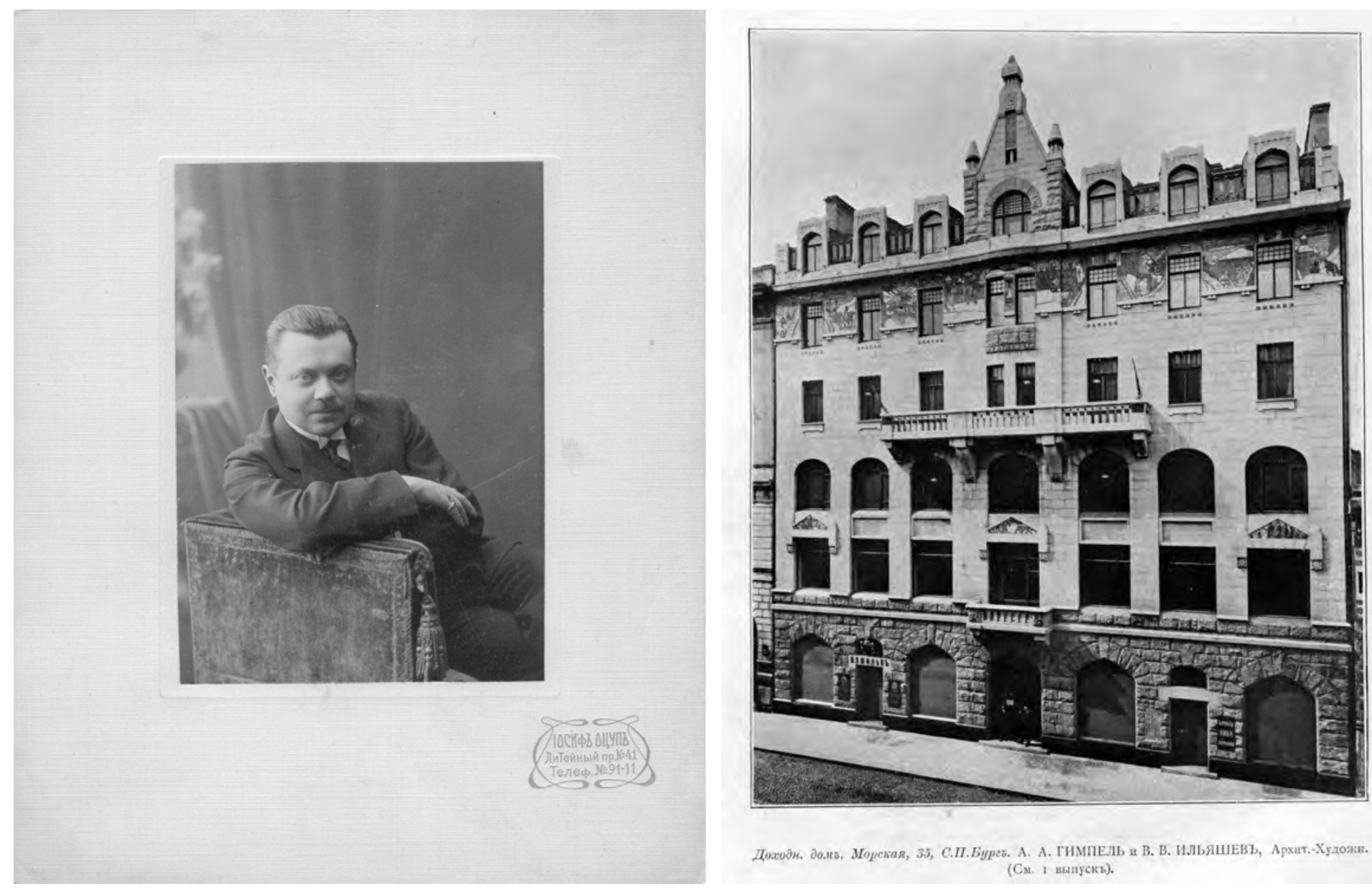

\begin{tabular}{l|l}
12 & 13 \\
\hline 14 &
\end{tabular}

12. А.В. Руманов.

Фотография 1915 года. Частный архив

13. Дом страхового общества «Россия" в Петербурге на Большой Морской улице, 35 , на мансардном этаже которого (справа) находилась квартира Румановых [3, c. 107]

14. Фрагмент фасада дома 35 по Большой Морской улице

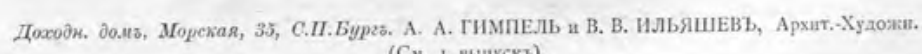
в Санкт-Петербурге. Современный вид. Фото Е.П. Яковлевой

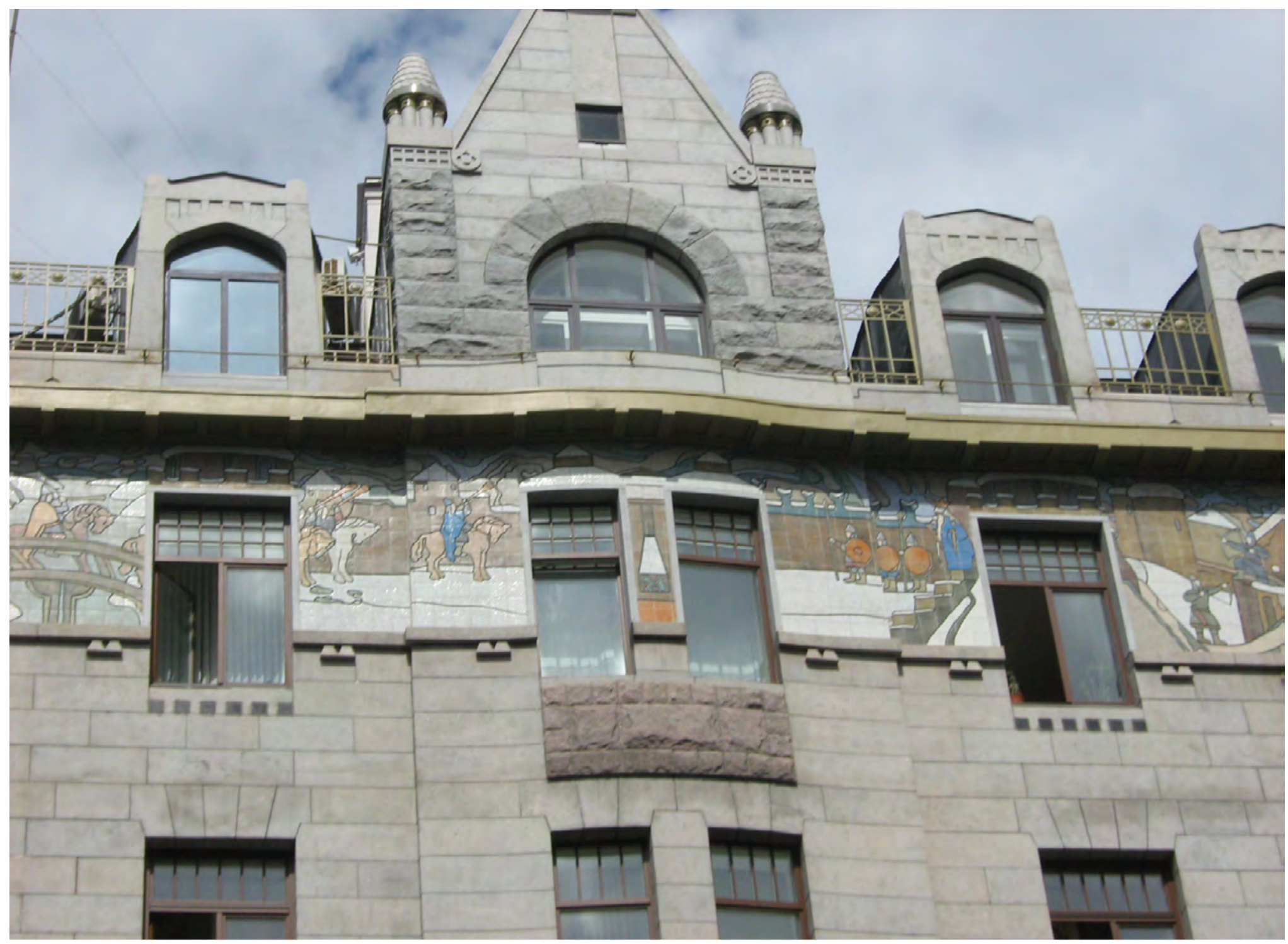




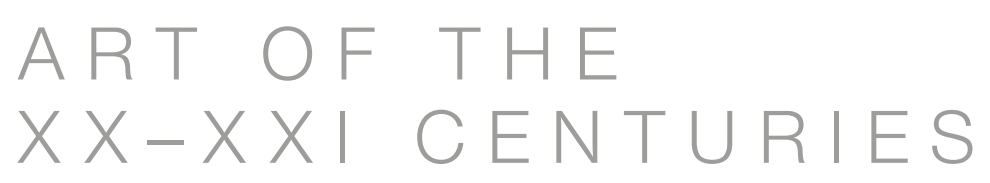

15. Березовый парк в имении Островки. Фотография начала 1900-х.

Частный архив

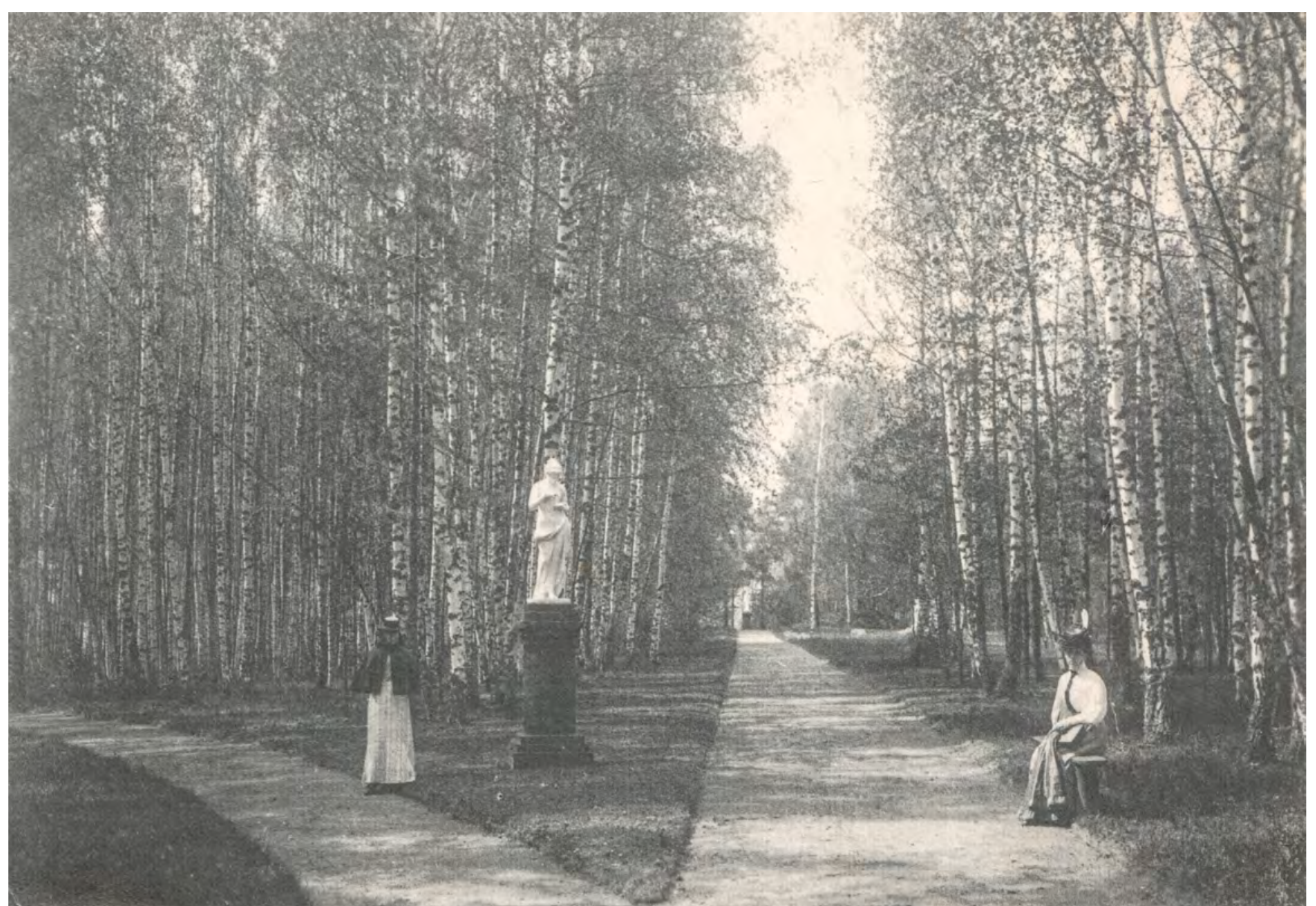

Согласно акту выдачи № 255 от 2 февраля 1930 года, пастель «Дорожка» на постоянное хранение во Владивостокский музей передал Государственный Русский музей в числе других тридцати четырех картин и икон, среди которых были пейзажи маслом И.И. Левитана, Н.П. Крымова и других художников [9].

В Русском музее пейзаж «Дорожка» хранился с 1920 года, когда в составе частной коллекции он поступил из освобождаемой после революции 1917 года квартиры известного петроградского журналиста и юриста Аркадия Вениаминовича Руманова (рис. 12) [23] и его жены, пианистки Женни Штембер, или Евгении Львовны Румановой, проживавших в столице по адресу: Большая Морская улица, дом 35, квартира 11 [22, с. 28].

Дом, построенный в 1908 году в стиле северного модерна, расположен напротив здания Императорского общества поощрения художеств, в котором, как известно, размещалась Рисовальная школа этого Общества. Директором школы с 1906 по 1916 год был Николай Константинович Рерих. Художник с семьей жил в том же здании, Рерих и Руманов, таким образом, были соседями.
На протяжении многих лет их связывали дружеские отношения, находившие отражение в деятельности Рериха и в художественном собирательстве Руманова [22]. Любопытный факт: фасад дома Страхового общества «Россия», в котором жил Аркадий Руманов на Большой Морской улице, украшали майоликовые композиции на тему древнерусского воинства, выполненные в 1900-е годы по эскизам Рериха (рис. 13, 14) [20].

Создание художественной коллекции Румановых восходит к концу 1900-х годов. Вероятно, тогда же в ее состав вошел этюд «Дорожка», написанный в имении Островки князя А.А. Ширинского-Шихматова - археолога, коллекционера и общественного деятеля, где поблизости, в селе Березки Н.К. Рерих с семьей проводил лето 1908 года [12, с. 216]. «Имение Островки располагалось в двух верстах от станции ЗаречьеАкадемическая Николаевской железной дороги в Подольской волости Вышневолоцкого уезда Тверской губернии» [7, с. 281]. В начале XX века Островки посещали многие известные деятели науки, культуры, духовенства. Сохранилась фотография березового парка в Островках с двумя 

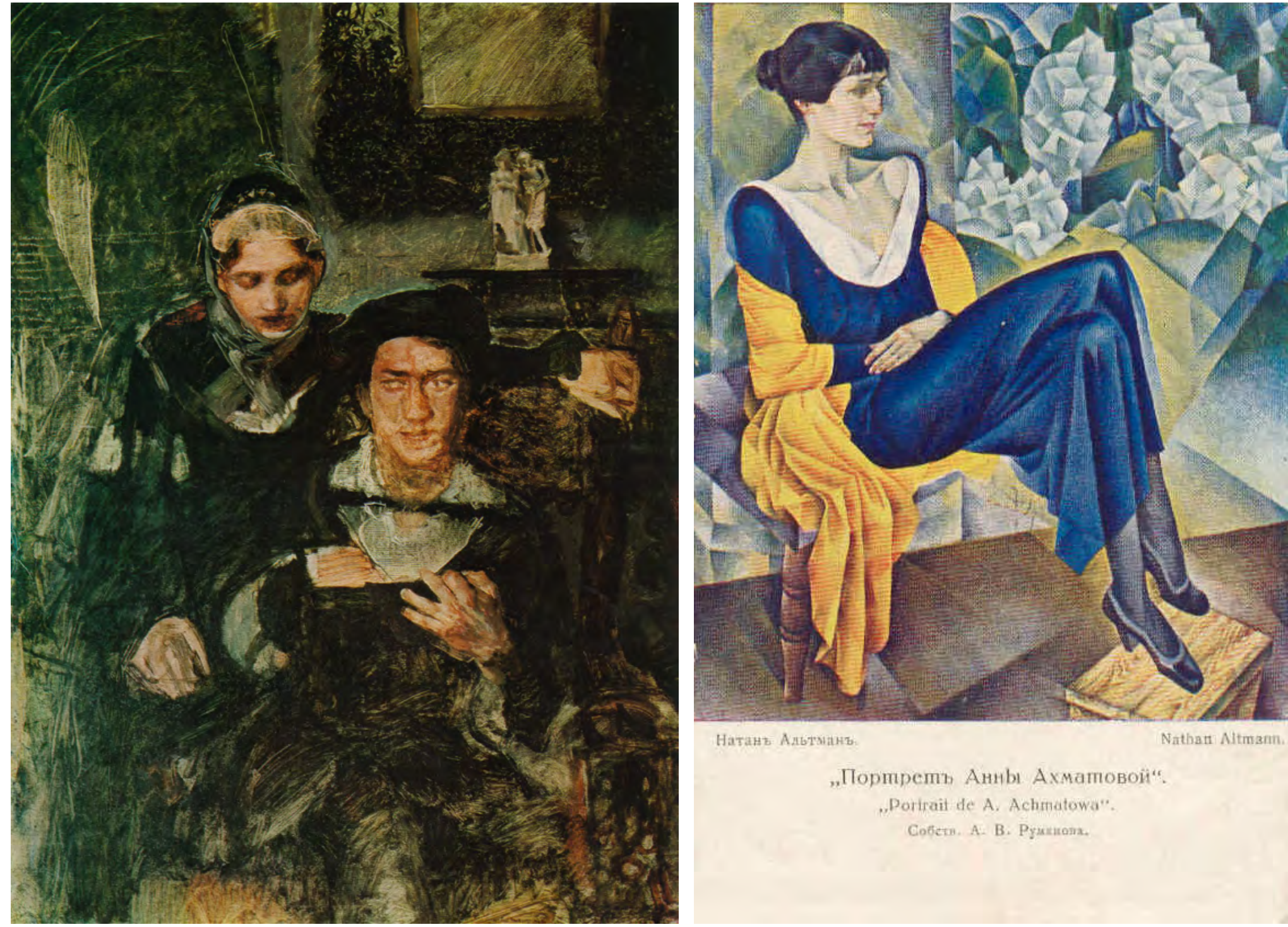

дорожками (рис. 15). Левая, с лежащими на ней тенями от густо посаженных берез, напоминает написанную пастелью «Дорожку» Н.К. Рериха.

В 1910-е годы это произведение являлось уже частью большой коллекции Румановых, в которую входили произведения русских и зарубежных художников. В их числе были такие шедевры, как неоконченная картина «Гамлет и Офелия» М.А. Врубеля (1884, рис. 16), «Портрет Анны Ахматовой» работы Н.И. Альтмана (1915, рис. 17) и другие картины, рисунки, скульптура, произведения декоративноприкладного искусства [22].

Установлено, что собирать коллекцию Руманову помогал Рерих [18, с. 239]. Неслучайно в ее состав в 1910-е годы входили двадцать две работы этого художника [18, с. 237-249; 19, с. 327]. Среди них произведения из фондов современного Русского музея: «Воскресенский монастырь в Угличе» (1904), «Илья Пророк» (1907), «Городок» (1907), эскизы декораций и костюмов к драме «Пер Гюнт» (1911-1912), поставленной в Московском Художественном театре (1912), эскизы к опере (1908) и драме (1912) «Снегурочка», к балету «Весна священная» (1912, рис. 18), поставленному антрепризой «Русский балет С.П. Дягилева» в Париже (1913), а также картины «Вестник» (1914), «Холмы» (1915), графические листы «Бой» (1912), «Валуны. Могила великана» (1915) и др. [18; 22].

Ранний этюд Н.К. Рериха «Идол» (1901) ныне хранится в Краснодарском краевом художественном музее имени Ф.А. Коваленко, картина «Мехески — лунный народ» - в Государственном музее искусств Республики Татарстан, пятнадцать произведений русских и западноевропейских художников - в современном собрании Омского музея изобразительных искусств имени М.А. Врубеля и т.д. [18; 22]. Всё собрание, за исключением коллекции старинных монет, размещалось в квартире Румановых, служившей с 1907 по 1912 год одновременно офисом петербургского отделения газеты И.Д. Сытина «Русское слово». Руманов был заведующим этого отделения. Интерьер квартиры знаменитого журналиста в шутливой форме описал поэт Владимир Пяст: «В гостиной - потолок покатый; / На стенах - живопись модерн: / И Врубель, Демоном проклятый, / И Сомов,
16. М.А. Врубель. Гамлет и Офелия.

1884 (не окончено). Холст, масло. $120 \times 89$ Государственный Русский музей. Фото: rmgallery.ru

17. Почтовая карточка 1915 года с портретом Анны Ахматовой работы Н.И. Альтмана. 1915

Собрание А.В. Руманова [10] 


\section{ART OF THE

18. Н.K. Рерих.

Поцелуй Земле.

Эскиз декораций

к балету

«Весна священная».

2-й вариант.

1912.

Картон, темпера.

$62 \times 94$

Государственный

Русский музей

[21, с. 132, № 70]

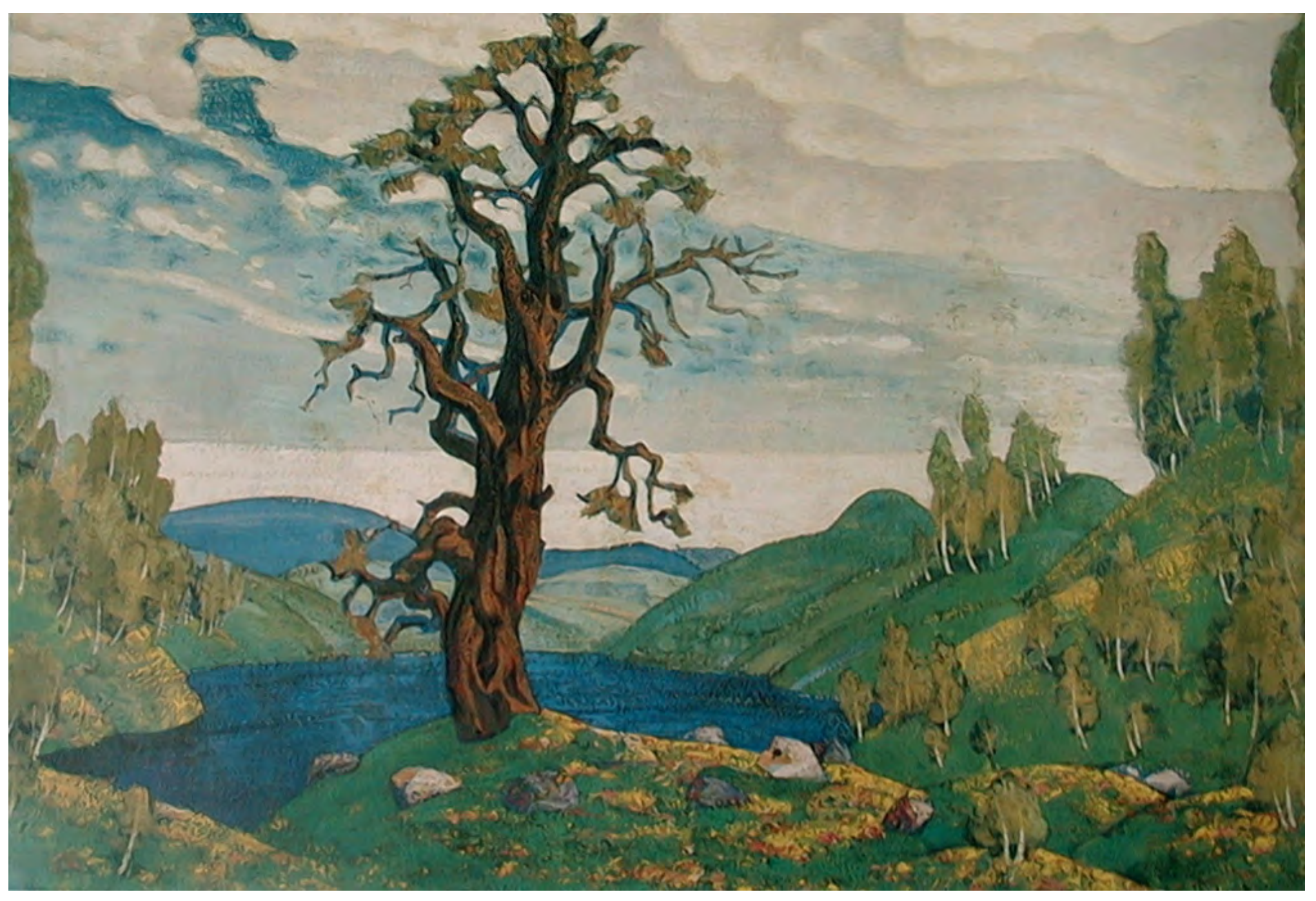

тайновидец скверн. / Под сенью их на миньятюрных / Игрушках-креслицах сидят: / То ряд имен литературных, / То - коммивояжеров ряд. / Часами, черным никотином / Старательно - и это труд - / Кладя осадок по картинам, / минутного приема ждут» [22, с. 28].

Таким образом, среди произведений коллекции Румановых камерный этюд «Дорожка» смотрелся вполне органично. Хотелось бы, чтобы и в собрании Приморской картинной галереи этот пастельный этюд сохранял шлейфр румановской коллекции. 


\section{Литература}

1. Выставка «Художники "Мира искусства”. Исторические прогулки. К 120-летию основания объединения «Мир искусства»: Каталог / автор идеи и координатор проекта И. Полторак. Санкт-Петербург: [б. и.], 2019. 154 с.

2. Дубль-вэ. Три выставки картин // Петербургский листок. 1909. 4/17 января. № 3.

3. Ежегодник Общества архитекторов-художников. Выпуск второй. Санкт-Петербург: Типография Т-ва А.Ф. Маркс, 1907.160 с.

4. Живопись первой половины XX века (H-P). Том 12 / научный редактор тома В.А. Леняшин. Санкт-Петербург: Palace Editions,

2014. 288 с. (Альманах; вып. 404 / Государственный Русский музей).

5. Каталог VII выставки картин Союза русских художников. Москва: Товарищество типографии А.И. Мамонтова, 1909-1910. 28, [1] с.

6. Лазаревский И. «Салон» III // Слово. 15/28 января 1909 года. № 679.

7. Мельников В.Л. О частных усадебных музеях в России во второй половине XIX - начале XX века. Музеи в селах Рютино и Бологое и в имении Островки // Собирательство как феномен культуры: материалы ХІІ Боголюбовских чтений. Саратов: СГХМ имени А.Н. Радищева, 2011. С. 279-288.

8. Николай Рерих, 1874-1947 / сост.: Г. Кречина, Ю. Солонович. Санкт-Петербург: Palace Editions, 2014. 228 с. (Альманах; вып. 406 / Государственный Русский музей).

9. Отдел учета ГРМ (Государственного Русского музея). Акт передачи № 255 от 2 февраля 1930 г.

10. Почтовая карточка. Петроград: Тип. И.В. Леонтьева, [1915]. 1 л.

11. Приморская государственная картинная галерея. Владивосток: каталог / составители: О. Батиевская, А. Даценко. Москва: Белый город, 2006. 64 с. ил.

12. Рерих Н.К. Десять сказок и притч Н.К. Рериха / текст Ю.К. Балтрушайтиса, А.Н. Бенуа, А.И. Гидони, А.М. Ремизова, С.П. Яремича; художественная редакция В.Н. Левитского. Петроград: Свободное искусство, [1916]. 232 с.; с ил. в тексте и 30 ил. на отдельных листах.

13. [Рерих] Н. Рерих из собрания Государственной Третьяковской галереи / автор-составитель А.М. Лукашов. Москва: Изобразительное искусство, 1989. 48 с.

14. Салон 1908-1909: Каталог [выставки живописи, графики, скульптуры и архитектуры, устроенной в 1909 году в помещении музея и в «Меншиковских комнатах» Первого кадетского корпуса]. [Санкт-Петербург]: Типография «Якорь» 1909.113 с.

15. Соколовский В.В. Художественное наследие Николая Константиновича Рериха: (Перечень произведений с 1885 по 1947 год) // Н.К. Рерих. Жизнь и творчество: Сб. ст. / НИИТИИИ.; главный редактор М.Т. Кузьмина. Москва: Изобразительное искусство, 1978. C. 259-304.

16. Центр-Музей имени Н.К. Рериха. Каталог. Живопись и рисунок. Николай Рерих. Святослав Рерих. Юрий Рерих. Елена Рерих / под общей редакцией Л.В. Шапошниковой. В 2 томах. Том 2. Москва: Международный Центр Рерихов, Мастер-Банк, 2010. $868 \mathrm{c}$.

17. Эрнст С. Н.К. Рерих. Петроград: Изд. Общины св. Евгении, 1918 (серия «Русские художники»). 126 с., [10] с., 7 л. цветных ил., 34 л. ил.

18. Яковлева Е.П. Н.К. Рерих и А.В. Руманов: художник и коллекционер // Федор Степанович Рокотов: актуальные проблемы творчества; от Павла Третьякова до Леонида Талочкина: коллекционеры-дарители XX века: материалы научных конференций. Москва: Государственная Третьяковская галерея, 2017. С. 235-249.

19. Яковлева Е.П. О дореволюционных владельцах произведений Н.К. Рериха // Рериховское наследие. Труды конференции. Т. 1. Санкт-Петербург: Издательство СПбГУ, 2002. С. 322-328.

20. Яковлева Е.П. О майоликовых панно на доме страхового общества «Россия» (Санкт-Петербург, Большая Морская улица, 35) // Н.К. Рерих и его современники. Коллекции и коллекционеры: Материалы научно-практической конференции: 2009. Вып. 8: Сборник статей. Одесса: Астропринт, 2010. С. 63-72.

21. Яковлева Е.П. Театрально-декорационное искусство Н.К. Рериха. Самара: Издательство «Агни», 1996. 272 с.

22. Яковлева Е.П. Художественное собрание А.В. Руманова // Коллекционеры. Санкт-Петербург - Петроград - Ленинград Санкт-Петербург. 1905 - 2015 / составители В.П. Березовский, Ю.М. Гоголицын. В 2 томах. Том 2. Статьи, воспоминания, фотодокументы. Санкт-Петербург: KGallery, НП-Принт, 2019. С. 25-38.

23. Яковлева Е.П., Чернобаева А.Ю. Руманов А.В. // Русские писатели 1800-1917: Биографический словарь. Т. 5 / под ред. П.А. Николаева. Москва: Большая Российская энциклопедия, 2007. С. 386-389.

24. Yaremenko A.V., B.S., M.B.A. Nicholai Konstantinovich Roerich: His Life and Creations During the Past Forty Years, 1889-1929. New York: Central Book Trading Company, 1931. 47 p., 122 pl.

ИНФОРМАЦИЯ ОБ АВТОРЕ: ЯКОвлева Елена Пантелеевна - доктор искусствоведения, ведущий научный сотрудник, Российский институт истории искусств, г. Санкт-Петербург, Российская Федерация, avmonal@yandex.ru

ABOUT AUTHOR: Yakovleva, Elena Panteleevna - D. Sc. (Art History), Leading Researcher, Russian Institute of Art History, St. Petersburg, Russian Federation, avmonal@yandex.ru 


\section{References}

1. Vystavka "Khudozhniki Mira iskusstva". Istoricheskiye progulki [Exhibition "Artists of the World of Art". Historical walks. Catalog]. Saint Petersburg, S. n., 2019. 154 p. (In Russian).

2. Dubl'-ve. Tri vystavki kartin [Double-ve. Three exhibitions of paintings]. Peterburgskiy listok — Petersburg leaflet, 1909, January 4/17, No. 3. (In Russian).

3. Yezhegodnik Obshchestva arkhitektorov-khudozhnikov [Yearbook of the Society of Artists Architects]. Issue 2. St. Petersburg, A.F. Marks Publ., 1907.160 p. (In Russian).

4. Zhivopis' pervoy poloviny XX veka (N-R). Tom 12 [Painting. First Half of the Twentieth Century (N, O, P, R)]. Issue 404. Palace Editions, St. Petersburg, 2014. 288 p. (In Russian).

5. Katalog VII vystavki kartin Soyuza russkikh khudozhnikov [Catalog of the 7th exhibition of paintings of the Union of Russian Artists]. Moscow, A.I. Mamontov Printing Company, 1909-1910. 28 p. (In Russian).

6. Lazarevsky I. "Salon" III ["Salon" III]. Word - Slovo, 1909, January 15/28, No. 679. (In Russian).

7. Melnikov V.L. O chastnykh usadebnykh muzeyakh v Rossii vo vtoroy polovine XIX - nachale XX veka [On the private estate museums in Russia in the second half of the 19th - early 20th century. Museums in the villages of Ryutino and Bologoye and in the Ostrovki estate]. Sobiratel'stvo kak fenomen kul'tury: materialy XII Bogolyubovskikh chteniy [Collecting as a phenomenon of culture: materials of the 12th Bogolyubov Readings]. Saratov, Saratov State Art Museum, 2011, pp. 279-288. (In Russian).

8. Krechina G., Solonovich Yu. (comp.). Nicholas Roerich, 1874-1947. Almanac of the State Russian Museum, issue 406. St. Petersburg: Palace Editions, 2014. 228 p. (In Russian).

9. Accounting Department of the State Russian Museum. Transfer Act No. 255 of February 2, 1930. (In Russian).

10. Pochtovaya kartochka [Postcard]. Petrograd, I.V. Leontyev Publ., [1915]. (In Russian).

11. Batiyevskaya O., Datsenko A. (comp.). Primorskaya gosudarstvennaya kartinnaya galereya. Vladivostok [Primorye State Art Gallery Vladivostok: catalog]. Moscow, Bely Gorod Publ., 2006. 64 p. (In Russian).

12. Roerich N.K. Desyat' skazok i pritch N.K. Roerikha [Ten fairy tales and parables of N.K. Roerich]. Petrograd, Svobodnoye iskusstvo Publ., [1916]. 232 p. (In Russian).

13. Lukashov A.M. (comp.). N. Roerikh iz sobraniya Gosudarstvennoy Tret'yakovskoy galerei [N. Roerich from the collection of the State Tretyakov Gallery]. Moscow, Izobrazitel'noye iskusstvo Publ., 1989. 48 p. (In Russian).

14. Salon 1908-1909: Katalog [Salon 1908-1909: Catalogue]. St. Petersburg, Tipografiya "Yakor", 1909. 113 p. (In Russian).

15. Sokolovsky V.V. Khudozhestvennoye naslediye Nikolaya Konstantinovicha Roericha: (Perechen' proizvedeniy s 1885 po 1947 god)

[The artistic heritage of Nikolai Konstantinovich Roerich: (List of works from 1885 to 1947)]. Kuzmina M.T. (ed.). N.K. Roerikh. Zhizn'

i tvorchestvo [N.K. Roerich. Life and creativity]. Moscow, Izobrazitel'noye iskusstvo Publ., 1978, pp. 259-304. (In Russian).

16. Shaposhnikova L.V. (ed.). Tsentr-Muzey imeni N.K. Roerikha. Katalog. Zhivopis' i risunok. Nikolay Roerikh. Svyatoslav Roerikh. Yuriy Rerikh. Yelena Roerikh [Center-Museum named after N.K. Roerich. Catalog. Painting and drawing. Nicholas Roerich. Svyatoslav Roerich. Yuri Roerich. Elena Roerich]. Vol. 2. Moscow, International Center of the Roerichs, Master Bank, 2010. 868 p. (In Russian).

17. Ernst S. N.K. Roerich. Petrograd, Community of St. Eugenia Publ., 1918. 126 p. (In Russian).

18. Yakovleva E.P. N.K. Roerikh i A.V. Rumanov: khudozhnik i kollektsioner [N.K. Roerich and A.V. Rumanov: artist and collector]. Fedor Stepanovich Rokotov: aktual'nyye problemy tvorchestva [Fyodor Stepanovich Rokotov: actual problems of creativity. Proceedings of the Conference]. Moscow, State Tretyakov Gallery, 2017, pp. 235-249. (In Russian).

19. Yakovleva E.P. O dorevolyutsionnykh vladel'tsakh proizvedeniy N.K. Roerikha [On the pre-revolutionary owners of the works of N.K. Roerich]. Rerikhovskoye naslediye. Trudy konferentsii [Roerich heritage. Proceedings of the Conference]. Vol. 1. St. Petersburg, St. Petersburg State University, 2002, pp. 322-328. (In Russian).

20. Yakovleva E.P. O mayolikovykh panno na dome strakhovogo obshchestva "Rossiya" (Sankt-Peterburg, Bol'shaya Morskaya ulitsa, 35) [About majolica panels on the house of the insurance company "Russia" (St. Petersburg, Bolshaya Morskaya Street, 35)]. N.K. Roerikh $i$ yego sovremenniki. Kollektsii $i$ kollektsionery [N.K. Roerich and his contemporaries. Collections and collectors. Proceedings of the Conference]. Issue 8. Odessa, Astroprint, 2010, pp. 63-72. (In Russian).

21. Yakovleva E.P. Teatral'no-dekoratsionnoye iskusstvo N.K. Roerikha [Theatrical and decorative art of N.K. Roerich]. Samara, Agni Publ., 1996. 272 p. (In Russian).

22. Yakovleva E.P. Khudozhestvennoye sobraniye A.V. Rumanova [Art collection of A.V. Rumanov]. Berezovsky V.P., Gogolitsyn Yu.M. (comp.). Kollektsionery. Sankt-Peterburg - Petrograd - Leningrad - Sankt-Peterburg. 1905-2015 [Collectors. St. Petersburg - Petrograd - Leningrad - St. Petersburg. 1905-2015]. Volume 2. Articles, memoirs, photo documents. St. Petersburg, KGallery, NP-Print, 2019, pp. 25-38. (In Russian).

23. Yakovleva E.P., Chernobaeva A.Yu. A.V. Rumanov [A.V. Rumanov]. Nikolayev P.A. (ed.). Russkiye pisateli 1800-1917: Biograficheskiy slovar [Russian writers 1800-1917: Biographical dictionary]. Vol. 5. Moscow, The Great Russian Encyclopedia, 2007, pp. 386-389. (In Russian).

24. Yaremenko A.V., B.S., M.B.A. Nicholai Konstantinovich Roerich: His Life and Creations During the Past Forty Years, 1889-1929. New York, Central Book Trading Company, 1931. 47 p., 122 pl.

\section{Для цитирования |For citation:}

Яковлева Е.П. О произведениях Н.К. Рериха в Приморской государственной картинной галерее // Искусство Евразии [Электронный журнал]. 2021. № 4 (23). C. 58-71. DOI: https://doi.org/10.46748/ARTEURAS.2021.04.005. URL: https://eurasia-art.ru/index.php/art/article/view/791

Yakovleva E.P. On the works of Nicholas K. Roerich in the Primorye State Art Gallery. Iskusstvo Evrazii — The Art of Eurasia, 2021, No. 4 (23), pp. 58-71. DOl: https://doi.org/10.46748/ARTEURAS.2021.04.005. Available at: https://eurasia-art.ru/index.php/art/article/view/791 (In Russian). 